\title{
Environmental problems of the oil and gas industry in Kazakhstan
}

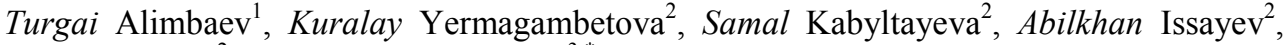 \\ Zhadyra Kairat ${ }^{2}$, and Zhanna Mazhitova, ${ }^{3, *}$ \\ ${ }^{1}$ Buketov Karaganda State University, Karaganda, Republic of Kazakhstan \\ ${ }^{2}$ L. N. Gumilyov Eurasian National University, Nur Sultan, Republic of Kazakhstan \\ ${ }^{3}$ Astana Medical University, Nur Sultan, Republic of Kazakhstan
}

\begin{abstract}
This article examines the environmental problems of the oil and gas sector in the Republic of Kazakhstan. The authors emphasize that for many decades the oil fields of Kazakhstan have developed mainly a raw material management system with extremely high technogenic loads on the environment. It is noted that for Kazakstani economy, oil and gas production and especially their export play a key role in generating income and growth within the gross product. At the same time, the authors point out that the impact of the oil and gas field on the environment in recent years has been characterized by its intensity, diversity and significant scale. The issue of developing new hydrocarbon raw materials deposits is considered, which is accompanied by geological exploration, drilling and construction works, laying of pipelines and roads. The authors come to the conclusion that a strong anthropogenic impact on all components of the environment causes an active change in the chemical and physicochemical properties of the soil, disrupts the hydrological regime of territories, leads to impoverishment and changes in the species composition, structure and productivity of phytocenoses, a reduction in the spatial distribution and number of animal populations. In conclusion, the authors put forward a number of fundamental tasks for solving environmental problems of the industry.
\end{abstract}

\section{Introduction}

The annexation of the Kazakh steppe to the Russian Empire led to the gradual involvement of the region into the sphere of capitalist relations, which made many changes in the socio-economic life of the population [1]. In particular, new sectors of the economy have developed in Kazakhstan, among which oil production in Western Kazakhstan should be mentioned [2].

The oil and gas industry of the Republic of Kazakhstan as one of the leading branches of industrial production is the basis for the development of the economy largely determining the economic independence of the country. Today it is already generally accepted that at least until the end of the third decade of the 21 st century the oil and gas

*Corresponding author: mazhitova_69@mail.ru 
industry of the Republic of Kazakhstan will be the only driving force that will be able to bring the Kazakhstani economy to the forefront of the world community and ensure fundamental changes in all spheres of life of the population of the republic.

In terms of proven reserves of hydrocarbon raw materials, the republic is one of the ten largest oil powers in the world giving ground only to certain states of the Middle East, Latin America, as well as Russia and the United States. The share of Kazakhstan in the world's proven hydrocarbon reserves is $3.2 \%$ for oil (4.6 billion tons), and for gas $-1.5 \%$ $\left(2.2\right.$ trillion $\left.\mathrm{m}^{3}\right)$. As for the share of predicted resources, it reaches $8 \%$ (17 billion tons) for oil, and for gas $-3.4 \%\left(146.4\right.$ trillion $\left.\mathrm{m}^{3}\right)$. In terms of oil production, Kazakhstan currently ranks $18^{\text {th }}$ in the world (and $2^{\text {nd }}$ in the CIS) after the countries of the Middle East, Russia, Venezuela, China, Norway, Canada, Great Britain, Indonesia, Brazil and some African states. At the same time, it should be noted that the main consumers of hydrocarbons are the USA, Japan, China, Korea, India and European countries (60\% of world consumption) [3]. This imbalance between the level of production and the level of consumption determines the leadership in the world energy market of oil exporting states. Therefore, for the next 30 years, the Republic of Kazakhstan should consider its domestic oil and gas industry as a priority industry that largely determines the development of the national economy.

The Republic of Kazakhstan has long been one of the most promising oil and gas regions. In its western part, practically all hydrocarbon deposits are concentrated, which are at the stage of industrial development. During the 80s, promising oil and gas-containing structures were identified in other zones: in the south (Zhambyl, Kyzylorda regions), east (East Kazakhstan region), which to a certain extent made it possible to treat differently the patterns of distributing this type of mineral in the republic. At the moment, in terms of proven oil reserves, Kazakhstan is among the fifteen leading countries in the world, and significant reserves of hydrocarbon raw materials make up 3.3\% of the world reserves.

\section{Materials and methods}

The study is based on the general research principles of historicism and objectivity. Applying these methods in the research enables to consider scientific knowledge as an integral system in which each previous approach indirectly or directly influenced the next one. All this together made it possible to compile a systematic series of scientific and theoretical calculations on the given issue. The views of authors are discussed regardless of ethnocultural preferences and political inclinations, which necessitates a thorough comparison of facts and phenomena in aggregate, that is, a comprehensive study of the problem.

In addition, a systematic approach, which takes into account both the features of the research objects themselves and the factors that determine these features, is used in the paper. Such approaches allow to identify not only gaps in the studied subject, but also some particular aspects of the problem that might not have come to the scholars' attention for one reason or another. In general, this gives the opportunity to objectively compare these aspects and, on their basis, determine the prospects for further research.

\section{Discussion of the results}

\subsection{Problem statement}

Large-scale development of oil and gas fields characterized by a high content of toxic elements, the presence of the world's largest closed body of water - the Caspian Sea and a 
number of transit rivers - the Volga, Ural, Emba and others - further aggravated the ecological situation and required more attention in matters of environmental protection. The level of the Caspian Sea was subject to fluctuations and largely depended on the water systems that fed it and the meteorological conditions. A dangerous hydrological phenomenon was observed here - wind surges of the waters of the Caspian Sea. Such surges were repeated annually in the spring and autumn months. At the same time, significant areas were exposed to flooding. In addition to the fact that such surges caused great material damage, they were dangerous and environmentally harmful. When the territories of oil fields were flooded, the sea waters were polluted with oil products, which negatively affected the inhabitants of the sea, marine vegetation and microflora. The danger of flooding forced the construction of branch canals, dams and a number of other costly protective structures.

The Caspian Sea is known for its rich biological resources. 90\% of the world's sturgeon stocks are concentrated here. The shallow waters of the Caspian Sea were a nesting place and a stopover for a huge number of waterfowl. The Caspian coast was a resort area of the republic; the Ustyurt reserve was created here. Various complexes of minerals have been discovered in the region, the use of which is associated with a number of environmental problems. In particular, a feature of the explored Karachaganak gas and oil condensate, Tengiz oil and a number of other oil and gas fields was the high content of hydrogen sulfide and other sulfur compounds, which increased the environmental hazard during their development. The increase in oil and gas production is accompanied not only by an increase in the rate of withdrawal of non-renewable natural resources, but also by the introduction of harmful hydrocarbon pollutants into the environment, among which the most dangerous are crude oil, gas condensates, oil sludge, acid tar and other hazardous substances. As a result of active pollution, there is a change in the chemical and physicochemical properties of the soil, a violation of the hydrological regime of territories, impoverishment and changes in the species composition, structure and productivity of phytocenosis, a decrease in the spatial distribution and number of animal populations. Loss of biological diversity is currently a real environmental threat [4]. Often in the process of violation of the technology of production, transportation and processing of oil, especially during emergencies in which oil and gas emissions occur, there is environmental pollution with oil and oil products, saline formation waters, drilling fluids, chemical reagents, which leads to a violation of environmental balance of natural ecosystems. The evidence indicates that in Kazakhstan there is a process of active development of new hydrocarbon deposits, accompanied by geological exploration, drilling and construction work, the laying of pipelines, roads, the growth of settlements, which, in turn, has a strong anthropogenic impact on all components of the environment. In other words, all technological processes of oil and gas production and related activities are potential sources of environmental pollution.

\subsection{Soil ecology}

Particularly, it is necessary to analyze the state of the territories adjacent to the places of exploration, development and operation of hydrocarbon deposits. Nearly every drilling rig within a radius of $500-800$ meters is destroyed by $70-80 \%$ of vegetation. The construction and operation of wells is accompanied by the destruction of the soil cover by $80 \%$, contamination of the site with oil, drilling fluids and chemicals by $40 \%$. Soil contamination in some oil fields reaches a thickness of up to 10 meters [5]. It has been proven that getting into the soil and water oil brings a diverse set of chemical compounds that violate the existing biogeochemical balance in ecosystems, i.e., a change in the physical state of the environment, a violation of its water-air regime, the introduction of toxic substances, a 
change in the structure of the soil, a violation of the carbon-nitrogen balance, change in the migration ability of individual microelements in the soil. A dangerous consequence is that the impact of oil on the soil for a long time leads to changes in its microbiological properties. In particular, new specialized forms of microorganisms appear that are capable of oxidizing solid paraffins, gaseous hydrocarbons, and aromatic hydrocarbons. As for higher plants, they die immediately after soil contamination. This is due to the fact that oil is one of the most dangerous pollutants in the biosphere. It is a complex mixture of hydrocarbons and their derivatives, and each of these compounds can be considered as an independent toxicant.

\subsection{Environmental problems of water sources}

The most severe and dangerous in terms of consequences is the pollution of ground and surface fresh waters, as well as pollution of the marine environment, as is the case in the Caspian Sea. For groundwater and surface water sources, pollutants are usually oil, drilling and oil sludge and waste water. For example, the cuttings formed during well drilling can contain up to $7.5 \%$ oil and up to $15 \%$ organic chemicals used in drilling fluids. Sludge often accumulates in a relatively large volume during oil preparation. In this case, sludge can contain up to $80-85 \%$ oil, up to $50 \%$ mechanical impurities, up to $67 \%$ mineral salts and $4 \%$ surfactants. When developing oil fields on the shelf, even under normal oil production, each drilling rig throws the following amount of substances into the water (in tons): oil 30-120, drill cuttings - 150-400, drill workings - 200-1000 [6]. At present, about 70-90 thousand tons of oil hydrocarbons are annually supplied to the Caspian water area with river runoff, and 29 thousand tons from the coasts. A high concentration of oil products is noted throughout the entire sea mass, especially in its upper layer, and traces of oil have been found over an area of more than $800 \mathrm{sq}$. km around offshore drilling platforms. On the territory of Kazakhstan, the Caspian oil-producing region, especially the Atyrau and Mangistau regions, is subject to the strongest anthropogenic impact. To date, more than 4.3 million hectares of disturbed land have been identified here, including 1.5 million hectares of technogenic zones, 1.9 million hectares of degraded pastures, 0.6 million hectares of contaminated with oil products and 0.3 million hectares of land with radioactive contamination. The total area of oil pollution in Western Kazakhstan is 194 thousand hectares, and the volume of spilled oil is more than 5 million tons [7]. In general, it can be noted that there is a steady tendency towards the deterioration of the ecological situation in the Caspian basin in all available directions.

As noted above, the most severe and dangerous in terms of consequences is the pollution of ground and surface fresh water, as well as pollution of the marine environment, as is the case in the Caspian Sea, where the main objects of the oil and gas sector of Kazakhstan are concentrated. There are the following surface water bodies on the territory of the Atyrau region: four large rivers with a total length of $1002 \mathrm{~km}$ and nine small rivers with a total length of $348 \mathrm{~km}$, including up to $10 \mathrm{~km}$ long - seven rivers with a total length of $48 \mathrm{~km}$; up to $200 \mathrm{~km}$ - two rivers with a total length of $300 \mathrm{~km}$; from 200 to $500 \mathrm{~km}-$ one river $212 \mathrm{~km}$ long; over $500 \mathrm{~km}$ - three rivers. The main surface water sources of the Atyrau region are the northeastern coast of the Caspian Sea, the Zhaiyk, Uil, Emba, Sagiz rivers, the Kigach, Sharonov delta branches and other small rivers. All rivers of the Atyrau region have transit flow from the Russian Federation and Aktobe region. The Zhaiyk River (Ural) is the main source of water supply for the Caspian lowland. It originates from the slopes of the South Ural Mountains, crosses the border of Kazakhstan, flows through the territories of the West Kazakhstan and Atyrau regions and flows into the North Caspian. The total length of Zhaiyk is 2,534 km, on the territory of Kazakhstan $-1,084 \mathrm{~km}$, within the West Kazakhstan region $-761 \mathrm{~km}$. The total area of the river basin is $237,000 \mathrm{~km}^{2}$. The 
Zhaiyk River forms its flows in the upper part of the basin in the territory of the Russian Federation to the village of Kushum in the West Kazakhstan region, after which the river no longer has tributaries. Within the West Kazakhstan region, the river receives tributaries of the Chagan, Derkul, Utva, Barbastau. The Sharonova and Kigash rivers are channels and branches of the lower reaches of the Volga River, crossing the territory of Kazakhstan and flowing into the Caspian Sea on the territory of the Atyrau region. The Emba River originates on the western slopes of the Mugodzhar mountains, crosses the territory of the Aktobe and Atyrau regions and is lost among salty coastal bogs (sors), in full-flowing years the river reaches the Caspian Sea. In the Atyrau region, the actual annual inflow of the main rivers amounted to $13,923 \mathrm{~km}^{3}$ in 2018 .

The current state of the sewerage networks in Atyrau makes it possible to cover only about $45 \%$ of the urban area and about $30 \%$ of the Balykshi settlement. Water disposal of the right-bank and left-bank parts of the city is performed by separate sewerage systems. The territory of the city is characterized by a flat relief. The overwhelming majority of pumping stations are in a pre-emergency state. The absence of sewage treatment facilities negatively affects the ecological situation in the area. If in 2017 the volume of wastewater disposal in the region amounted to 18433.91 thousand $\mathrm{m}^{3}$, then in 2018 a decrease in volume was noted - 16971.82 thousand $\mathrm{m}^{3}$.

Data on actual discharges of pollutants and water disposal are presented in table 1 [8].

Table 1. Pollution of water resources and discharges of pollutants with wastewater.

\begin{tabular}{|c|c|c|c|}
\hline \multicolumn{2}{|c|}{$\begin{array}{c}\text { Information on the actual volumes of } \\
\text { discharges }\end{array}$} & \multirow{2}{*}{$\begin{array}{c}2017 \\
5010.71\end{array}$} & \multirow{2}{*}{$\begin{array}{c}2018 \\
6882.507\end{array}$} \\
\hline $\begin{array}{l}\text { Industrial } \\
\text { discharges }\end{array}$ & $\begin{array}{c}\text { Water disposal } \\
\text { volume, thousand } \mathrm{m}^{3}\end{array}$ & & \\
\hline & $\begin{array}{l}\text { Volume of pollutants, } \\
\text { thousand tons }\end{array}$ & 7.34 & 7.5 \\
\hline \multirow[t]{2}{*}{$\begin{array}{l}\text { Domestic waste } \\
\text { water }\end{array}$} & $\begin{array}{c}\text { Water disposal } \\
\text { volume, thousand } \mathrm{m}^{3}\end{array}$ & 13395.07 & 10089.312 \\
\hline & $\begin{array}{l}\text { Volume of pollutants, } \\
\text { thousand tons }\end{array}$ & 13.9 & 9.27 \\
\hline \multirow{2}{*}{$\begin{array}{l}\text { Emergency and } \\
\text { unauthorized } \\
\text { discharges }\end{array}$} & $\begin{array}{c}\text { Water disposal } \\
\text { volume, thousand } \mathrm{m}^{3}\end{array}$ & 28.12 & 29.1 \\
\hline & $\begin{array}{l}\text { Volume of pollutants, } \\
\text { thousand tons }\end{array}$ & 0.04 & 0 \\
\hline \multirow{2}{*}{$\begin{array}{l}\text { Total (all of the } \\
\text { above } \\
\text { discharges) }\end{array}$} & $\begin{array}{c}\text { Water disposal } \\
\text { volume, thousand } \mathrm{m}^{3}\end{array}$ & 18433.91 & 16971.82 \\
\hline & $\begin{array}{l}\text { Volume of pollutants, } \\
\text { thousand tons }\end{array}$ & 21.9 & 16.8 \\
\hline
\end{tabular}

\subsection{Environmental crisis in the air}

A significant increase in oil production in recent years has naturally led to a sharp deterioration in the environmental situation in the region. In the cities of Western Kazakhstan, there is a high level of air pollution, with the prevailing pollutants from oil and gas production and oil refining. The level of air pollution in the region is determined mainly by five large enterprises: CNPC-AktobeMunaygaz JSC, KazakhOilAktobe LLP, Aktobe Ferroalloy Plant and DGOK, branches of TNK Kazchrome JSC, Intergas CA JSC, Aktobe UMG, JSC Aktobe CHP. The number of emission sources is presented in table 2 [9].

Compared to 2017, the total volume of air emissions from stationary sources in 2018 decreased by $7.2 \%$ (in thousand tons): in 2017 - 169.5; in 2018 - 158.1. The main air pollutants are carbon monoxide, sulfur dioxide, particulate matter, and nitrogen oxide. 
Table 3. shows the emissions by major pollutants for 2017-2018. from stationary sources [10].

Table 2. The number of stationary sources of pollutant emissions for 2017-2018.

\begin{tabular}{|c|c|c|}
\hline $\begin{array}{c}\text { Number of stationary sources of pollutant } \\
\text { emissions }\end{array}$ & 2017 & 2018 \\
\hline & 22644 & 22745 \\
\hline
\end{tabular}

Table 3. Emissions from stationary sources.

\begin{tabular}{|l|c|c|}
\hline \multicolumn{1}{|c|}{ Contamination information } & 2017 & 2018 \\
\hline $\begin{array}{l}\text { Sulfurous anhydride (SO2) emissions, } \\
\text { thousand tons }\end{array}$ & 26.1 & 28.4 \\
\hline $\begin{array}{l}\text { The volume of nitrogen oxide emissions } \\
\text { (in terms of NO2) into the atmosphere, } \\
\text { thousand tons }\end{array}$ & 13.9 & 14.6 \\
\hline $\begin{array}{l}\text { The volume of emissions of particulate } \\
\text { matter into the air, thousand tons }\end{array}$ & 20.2 & 21.9 \\
\hline $\begin{array}{l}\text { The volume of carbon monoxide } \\
\text { emissions into the air, thousand tons }\end{array}$ & 47.5 & 42.3 \\
\hline
\end{tabular}

Of the total volume of emissions from stationary sources, the share of emissions from the flaring of associated gas amounted to 16.3 thousand tons. A decrease in the volume of associated gas flared in flares is associated with an increase in the volume of associated gas utilization. At the same time, the volume of associated petroleum gas production of CNPCAktobeMunayGas JSC in 2018 compared to 2017 increased by 194.237 million $\mathrm{m}^{3}$ (in 2018 -6155.107 million $\mathrm{m}^{3}$ of gas was produced against 5960.87 million $\mathrm{m}^{3}$ in 2017).

$97 \%$ of all emissions from flares are accounted for by three oil production and refining enterprises: CNPC-AktobeMunaygaz JSC, KazakhOilAktobe LLP and Aman Munai LLP. According to the Ministry of Internal Affairs, 187,464 units of vehicles were registered in 2018, of which 142703 units were with a gasoline engine, on gas fuel -44761 units. The total volume of pollutants emissions from vehicles in 2018 is 84.05 thousand tons against 82.67 thousand tons in 2017. The restraining factors for the growth of emissions into the atmosphere are the strengthening of control over emissions and the quality of imported fuels and lubricants, the conversion of vehicles to gas fuel, an increase in the share of new vehicles meeting the EURO-4 requirements. The share of gas-fueled vehicles in 2018 is $24 \%$. In order to reduce the load on the atmospheric air of the city of Aktobe, work was carried out to expand and reconstruct the roadbed and plant greenery in city streets. In 2018, the Department of Ecology, together with the internal affairs bodies, took measures to control emissions of pollutants from vehicles in the city of Aktobe, during which 884 units of vehicles were checked: 55 - on gasoline, 829 - on diesel fuel. At the same time, 61 facts of exceeding the level of toxicity were established, administrative measures were taken against the owners of vehicles. Also, 47 vehicles were randomly checked: 10 on gasoline and 37 on diesel fuel. As a result, nine facts of excess of the toxicity level were revealed [11].

At present, it is highly relevant to reduce environmental pollution by modernizing the oil and gas sector of the economy using the most efficient technologies, ensuring the investment attractiveness of measures for the efficient use of hydrocarbon resources, and creating a strategic "reserve" of hydrocarbon raw materials. The most important task at the present stage is the introduction of renewable energy sources. It is fundamentally important for Kazakhstan to rethink its attitude to its natural resources. The government must manage it correctly, accumulating income from their sale in the treasury, and most importantly, transforming the natural resources of our country into sustainable economic growth as 
efficiently as possible. In the modern period, mankind consumes a huge amount of natural resources, in particular, fuel and energy, among them a special role belongs to oil and gas, which are united by the concept of "hydrocarbon raw materials". The world has a huge number of problems associated with the use of hydrocarbon raw materials. They are of a political, economic, social and especially ecological nature. The high and ever-increasing growth of oil production and refining in the world leads to the fact that the level of environmental pollution by oil products is currently acquiring a global character. The Republic of Kazakhstan is no exception. More and more significant territories of Kazakhstan are involved in the sphere of anthropogenic development of oil and gas fields, the inevitable consequence of which is the deterioration of the environmental situation.

\section{Conclusion}

The state of the natural environment is one of the most acute socio-economic problems that directly or indirectly affect the interests of each person. Humanity transforms living and inanimate nature much faster than their evolutionary restoration takes place. The consumption of oil and gas is incomparable, for example, with the rate of their formation. Currently, humanity is in a period of over-intensive use of environmental resources, i.e., the consumption of resources exceeds their growth, which inevitably leads to the depletion of resources. The current ecological state of the territory of Kazakhstan can be defined as critical $[12,13]$. Intense pollution of the natural environment continues posing a real threat to the very biological foundations of the health and life of the country's population. In terms of the level of negative impact on the natural environment, oil and gas production takes one of the first places among industries and this impact is due to its characteristics. It pollutes almost all areas of the environment, i.e., the atmosphere, the hydrosphere, and not only surface but also groundwater. The increase in oil and gas production is accompanied not only by an increase in the rate of withdrawal of non-renewable natural resources, but also by the introduction of harmful hydrocarbon pollutants into the environment, among which the most dangerous are crude oil, gas condensates, oil sludge, acid tar and other hazardous substances. Loss of biological diversity is currently a real environmental threat. In the process of violation of the technology of production, transportation and processing of oil, especially during emergencies in which oil and gas emissions occur, there is often pollution of the environment with oil and oil products, saline formation waters, drilling fluids, chemical reagents, which leads to a violation of environmental balance of natural ecosystems.

In the oil and gas industry, as well as in Kazakhstan as a whole, it is necessary to solve a number of fundamental tasks as soon as possible: 1. Elimination of historical pollution, as well as sources of negative impact on the environment (inactive wells, waste water storage, landfills and other production facilities). 2. Reducing emissions into the environment by improving technological solutions, for example, replacing fuel oil with fuel / natural gas (as fuel in process furnaces), using new generation additives, replacing equipment, expanding production facilities for gas processing, construction of gas processing plants and so on. Improvement of measures for the protection of atmospheric air through the introduction of treatment facilities and installations. 3. Reduction of discharges of pollutants; modernization of wastewater treatment facilities. Increasing the efficiency of the use and protection of water resources, including improving the condition of small rivers, reservoirs, monitoring the condition of groundwater. 4. Solving the problems of rational use of land, including protection from wind and water erosion, flooding, waterlogging and salinization. Reducing the chemical load on the soil. 5. Creation of infrastructure for waste processing; expansion of the network of nature reserves, national parks and reserves. Strengthening 
work on the protection, reproduction and rational use of flora and fauna. Improving the health and quality of life of the population.

In these conditions, the priority direction of activity of state bodies should be the active use of economic, legal and organizational methods of influencing the emerging economic system, its maximum ecologization in order to balance the development of diverse processes, i.e., the economic development of the country and the creation of a favorable environment for human life and health. In economic terms, environmental problems should be solved at the expense of various sources, i.e., budget, extra-budgetary funds, enterprises, etc. Determining the optimal amount of funds to ensure the required level of the state of the environment is considered the most reasonable. A flexible combination of measures for direct regulation of the quality of natural resources and the environment and economic mechanisms of environmental management is needed: greening of technical and technological policies at industrial facilities, implementation of environmental monitoring systems, compilation of a data bank based on environmental passports of facilities and territories; greening of land and urban planning policy. Technologically, the priority areas of environmental policy at the beginning of the 21 st century should become a consistent transition to international environmentally friendly standards of technological processes and manufactured products. In our opinion, it is necessary to stimulate the introduction of low-waste, resource and energy-saving technologies and processes. Particular attention should be paid to the greening of the consciousness among natural resources users and the formation of appropriate public opinion, since the changes taking place in the world necessitate the formation of a holistic humanistic worldview in relation to nature, in which universal values will receive priority. At the same time, the specificity and variety of ecological and economic transformations require a differentiated approach to the development and implementation of the economic mechanism of nature management. This confirms the importance of developing long-term environmental programs as the main component of rational nature management and environmental protection in long-term plans for socio-economic development at the republican, regional and local levels.

\section{References}

1. Zh.S. Mazhitova, Place and Role of the Biy Council and People's Assembly in the Traditional Kazakh Society of the XVIII-XIX Centuries (Following the Data of the PreRevolutionary Russian Historiography), Asian Social Science 10, 20, 129-136 (2014)

2. History of Kazakhstan (from ancient times to the present day), In five volumes, Almaty: Atamura 3, 768 (2000)

3. Oil and gas 4, 24 (2016)

4. O.I. Yegorov, O.A. Chigarkina, A.S. Baimukanov, Oil and Gas Complex of Kazakhstan: Development Problems and Operational Efficiency, Almaty: Atamura 536 (2003)

5. A.A. Abrosimov, M.Yu. Dolomatova, E.G. Telyasheva, Ecology of processing of hydrocarbon systems, Moscow: Chemistry 81 (2002)

6. Yu.A. Podavalov, Ecology of oil and gas production, Moscow: Infra-Engineering 146 (2010)

7. Oil and gas, Strategic goals of NC KazMunayGas 16 (2017)

8. National report on the state of the environment and the use of natural resources of the Republic of Kazakhstan for 2018, Astana, 314 (2018)

9. National report on the state of the environment and the use of natural resources of the Republic of Kazakhstan for 2018, Astana, 314 (2019) 
10. Kazmunai gas annual report for 2019, Astana, 163 (2019)

11. National report on the state of the environment and the use of natural resources of the Republic of Kazakhstan for 2018, Astana, 315 (2017)

12. T. Alimbaev, Zh. Mazhitova, B. Omarova, B. Kamzayev, K. Atanakova. Ecological problems of modern central Kazakhstan: challenges and possible solutions, E3S Web of Conferences 157, 1-8 (2020)

13. T. Alimbaev, Zh. Mazhitova, Ch. Beksultanova, N. Tentigul Kyzy, Activities of mining and metallurgical industry enterprises of the Republic of Kazakhstan: environmental problems and possible solutions, E3S Web of Conferences 175, 1-9 (2020) 